\title{
Measurement of free insulin concentrations: the influence of the timing of extraction of insulin antibodies
}

\author{
I. Hanning, P.D. Home and K.G. M.M. Alberti \\ Department of Medicine, University of Newcastle upon Tyne, UK
}

\begin{abstract}
Summary. Plasma insulin concentrations of insulin-treated diabetic patients must be measured after removal of insulin antibodies, usually by precipitation with polyethylene glycol (PEG). Details of the procedure vary between laboratories; commonly, frozen plasma is thawed and incubated at $37^{\circ} \mathrm{C}$ to restore a presumed equilibrium between free and antibody bound insulin before extraction. The present study was designed to investigate methodological factors that could affect the measured free insulin concentration. In normal subjects PEG extraction of globulins did not disturb measurement of insulin concentrations, whether carried out after incubation for $2 \mathrm{~h}$ at $37^{\circ} \mathrm{C}$, or storage at $-20^{\circ} \mathrm{C}$, in either order. Freezing or incubation of PEG extracts of plasma from insulin-treated patients also failed to disturb the measured concentrations of free insulin. When plasma from patients was incubated for $2 \mathrm{~h}$ after storage, a marked scatter (51-272\%) of measured results occurred when compared to bedside extraction. This problem was not overcome by buffering with HEPES or storage at a lower temperature $\left(-40^{\circ} \mathrm{C}\right)$. Incubation at $0^{\circ} \mathrm{C}$ also severely
\end{abstract}

disturbed the apparent concentrations. Incubation of plasma before extraction and freezing also disturbed the measured result, a problem not corrected by maintaining near physiological $\mathrm{pH}$. Total insulin concentrations measured on acid extracts were not disturbed by any of these manoeuvres. The temperature of centrifugation of blood at the time of venepuncture did not influence the result. Furthermore, when insulin concentrations were rising or falling similar percentage changes were seen over a 30-min incubation of plasma before extraction on the day of venepuncture, suggesting that equilibrium between free and bound insulin is maintained in vivo. We suggest that, for accurate estimation of free insulin concentrations in insulin-treated diabetic patients, immediate centrifugation of blood and extraction of insulin antibodies is mandatory.

Key words: Insulin, free insulin assay, insulin antibodies, radioimmunoassay.

2h did not result in stable measured free insulin concentrations, with some samples giving higher values and some lower. This must cast doubt on the validity of their technique. Current methods have tended to be accepted because they give results that correspond in some way to the expected values. It is not even known if an equilibrium between free and antibody bound insulin is maintained in vivo when insulin levels are changing, so that the $37-{ }^{\circ} \mathrm{C}$ incubations may be based on a false premise.

We have therefore compared the free and total (free plus bound) insulin results achieved by removing insulin-antibody complexes from plasma immediately after venepuncture and rapid centrifugation of blood with results obtained by extraction on the day of assay after storage of frozen plasma. The effect of the timing of an incubation period, its $\mathrm{pH}$, and the temperature of storage were also investigated. Normal plasma was used to control for the effects of these procedures on insulin itself. Results obtained during rising free insulin levels were compared with those during falling insulin levels in an attempt to detect in vivo disequilibrium. The effect of other variables such as the temperature of centrifuga- 


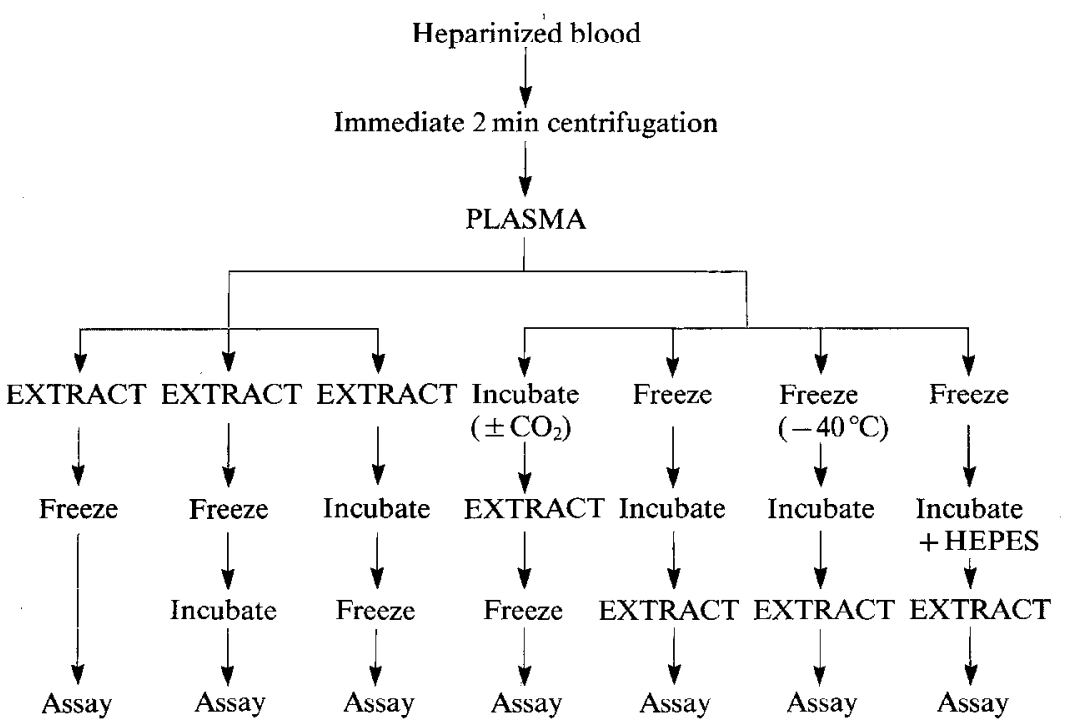

Fig. 1. Flow diagram of the protocols followed in Study 1. Plasma was extracted with $300 \mathrm{~g} / \mathrm{kg}$ polyethylene glycol. Storage was at $-20^{\circ} \mathrm{C}$ except as indicated. All incubations were at $37^{\circ} \mathrm{C}$ for up to $2 \mathrm{~h}$. Incubations with $\mathrm{CO}_{2}$ were at $5 \% \mathrm{CO}_{2}$ in air tion of blood and the temperature of incubation of plasma prior to extraction on the day of assay were also investigated.

\section{Methods}

\section{Study 1: Influence of storage of plasma at -20 and $-40^{\circ} \mathrm{C}$, and the $\mathrm{pH}$ of incubation}

Nine insulin-treated patients consented to participate in this part of the study. A single $60-\mathrm{ml}$ blood sample was taken from each patient, the time of day being varied so as to give a range of plasma insulin concentrations (11.3-31.9 mU/1). Blood was heparinized in standard hospital collection bottles (lithium heparin, Laboratory Sales, Rochdale, UK), and plasma separated by immediate centrifugation for $2 \mathrm{~min}$ at $4^{\circ} \mathrm{C}$. The final heparin concentration was $13 \mathrm{IU} / \mathrm{ml}$ of blood. This does not affect measured results in our insulin radioimmunoassay.

Duplicate aliquots of plasma were then handled as follows (Fig. 1): 1. Extracted immediately with equal volumes of ice-cold $300 \mathrm{~g} / \mathrm{kg}$ PEG 6000 (BDH Chemicals, Poole, UK) in the assay buffer, vortexed, centrifuged $\left(30 \mathrm{~min}, 4^{\circ} \mathrm{C}\right)$ and immediately stored at $-20^{\circ} \mathrm{C}$. 2. As (1), but with the extract incubated for $2.0 \mathrm{~h}$ at $37^{\circ} \mathrm{C}$ on the day of assay. 3. As (1), but with the extract incubated for $2.0 \mathrm{~h}$ at $37^{\circ} \mathrm{C}$ before storage at $-20^{\circ} \mathrm{C}$. 4 . Incubated as plasma in a $\mathrm{CO}_{2}$ incubator (to maintain $\mathrm{pH}$ ) for $0.5,1.0,1.5$, and $2.0 \mathrm{~h}$ at $37^{\circ} \mathrm{C}$ before extraction with PEG and storage at $-20^{\circ} \mathrm{C}$. 5. As (4), but without $\mathrm{CO}_{2}$. 6. Stored as plasma at $-20^{\circ} \mathrm{C}$ and incubated at $37^{\circ} \mathrm{C}$ for $0.5,1.0,1.5$, and $2.0 \mathrm{~h}$ before extraction with PEG on the day of assay [5]. 7. Stored as plasma at $-40^{\circ} \mathrm{C}$ and incubated at $37^{\circ} \mathrm{C}$ for $2.0 \mathrm{~h}$ before extraction with PEG on the day of assay. 8. Stored as plasma at $-20^{\circ} \mathrm{C}$, and $0.40 \mathrm{ml}$ buffered with $0.025 \mathrm{ml} 1 \mathrm{~mol} / 1$ HEPES (Sigma Chemical, Poole, UK) pH 7.4 before incubation at $37^{\circ} \mathrm{C}$ for $2.0 \mathrm{~h}$ and extraction with PEG on the day of assay.

Further duplicate aliquots of plasma were treated as (1) to (7) above, but subjected to acid extraction for total insulin estimation. For this purpose the plasma $(0.50 \mathrm{ml})$ was acidified with $0.10 \mathrm{ml}$ of $1.00 \mathrm{~mol} / \mathrm{l}$ hydrochloric acid and incubated at room temperature for $30 \mathrm{~min}$. Then $0.10 \mathrm{ml}$ of $1.00 \mathrm{~mol} / \mathrm{l}$ sodium hydroxide followed immediately by $0.70 \mathrm{ml}$ of $300 \mathrm{~g} / \mathrm{kg}$ PEG were added while the sample was being vortexed. Extracts, after centrifugation, were then treated as for the free insulin extracts. Serum was also obtained for insulin antibody and C-peptide analysis.

As a control to this study, blood was also taken from 10 normal control subjects at different times of day, and unextracted plasma in duplicate aliquots immediately frozen or subjected to a 2.0 -h incuba- tion at $37^{\circ} \mathrm{C}$ before or after freezing. These samples were measured in a standard insulin radioimmunoassay. Further aliquots of this normal plasma were treated in the same way as aliquots 1., 2., 3., 4., 5. and 6. (2.0-h incubation only) of the plasma from the insulin-treated subjects. A total insulin estimation was performed on frozen plasma.

\section{Study 2: Effect of temperature of centrifugation, and temperature of incubation of plasma during rising and falling insulin concentrations}

A further six insulin-treated diabetic patients consented to participate in this part of the study. On the day of study they had their normal breakfast, but took only their usual short acting insulin. At $11.00 \mathrm{~h}$, a polytetrafluoroethylene cannula was inserted into a forearm vein for intermittent blood sampling, being flushed after use with $0.5 \mathrm{ml}$ $0.15 \mathrm{~mol} / 1$ saline. At $12.00 \mathrm{~h}$ (time $0 \mathrm{~min}$ ), subjects were injected intramuscularly in the left deltoid with highly purified porcine neutral soluble insulin (Actrapid, Novo Industri, Bagsvaerd, Denmark), 12 to $20 \mathrm{U}$, depending on their usual insulin dose. All subjects received lunch at $+30 \mathrm{~min}$.

Blood samples were withdrawn at 10,20,30,120,150,180 min. At each time point a heparinized blood sample was immediately centrifuged ( $60 \mathrm{sec}$, room temperature) and plasma immediately extracted with PEG.

At $+20 \mathrm{~min}$ (rising free insulin concentrations) samples were also treated as follows: 1 . Blood was centrifuged at $4{ }^{\circ} \mathrm{C}$ and $37^{\circ} \mathrm{C}(60 \mathrm{sec})$ before PEG extraction. 2. Plasma from each of the three temperatures of centrifugation was incubated for $30 \mathrm{~min}$ at the same temperature before extraction with PEG. 3. Plasma was immediately frozen $\left(-20^{\circ} \mathrm{C}\right)$ and incubated for $2.0 \mathrm{~h}$ at 0 or $37^{\circ} \mathrm{C}$ before extraction on the day of assay.

At +150 minutes (falling insulin concentrations) samples were also treated as in 1. and 2. Samples were also taken for C-peptide and insulin antibody assay on serum.

\section{Assays}

Pre-extracted samples were thawed in ice-cold water prior to assay. Insulin was measured by double antibody radioimmunoassay $[8,9]$. The assay buffer in Study 1 was $0.05 \mathrm{~mol} / 1$ borate containing $3.7 \mathrm{~g} / 1$ potassium chloride and $0.24 \mathrm{~g} / 1$ thiomersal, adjusted to $\mathrm{pH} 8.0$ with sodium hydroxide. To this was added $2.5 \mathrm{~g} / 1$ bovine plasma albumin (fraction V, Armour Pharmaceutical, Eastbourne, UK). In Study 2 the buffer was $0.04 \mathrm{~mol} / 1$ sodium phosphate, $\mathrm{pH} 7.4$, containing $1 \mathrm{~g} / 1 \mathrm{hu}$ man albumin (fraction V, Sigma Chemical, Poole, UK), and $0.24 \mathrm{~g} / 1$ thiomersal. Guinea-pig anti-insulin serum (product code RD10), normal guinea-pig serum (CT01), rabbit anti-guinea-pig serum (RD18) and human insulin standard (RD13) were obtained from Wellcome 
Reagents Ltd. (Beckenham, UK). Iodinated bovine insulin (IM38) was obtained from Amersham International (Amersham, UK). A PEG extract of charcoal stripped normal plasma was included in the standard tubes to give identical PEG/protein concentrations to those of the sample tubes. All samples of each study were andlysed in a single assay to minimise the influence of assay variability.

The sensitivity of this assay is $2.5 \mathrm{mU} / \mathrm{l}$, with an intra-assay coefficient of variation of $7 \%$. Recovery of added insulin was $93 \pm 3 \%$ (mean $\pm S E$ ) from PEG extracts of plasma of non-insulin treated subjects, and $90 \pm 3 \%$ from the plasma of insulin-treated diabetic patients (extracted within $10 \mathrm{~s}$ of addition of insulin). The assay gives identical standard curves with human, porcine and bovine insulins. Recovery of insulin added to plasma from insulin-treated diabetic patients prior to acidification and subsequent extraction as for the total insulin assay (above) was $79 \pm 4 \%$. Assay of non-extracted plasma (from controls) was performed identically, except that the charcoal stripped normal plasma was not extracted with PEG.

Serum C-peptide was measured by radioimmunoassay with ethanol separation [10] (sensitivity $0.02 \mathrm{nmol} / 1$, intra-assay CV 3\%), and IgG specific insulin antibodies by an immunochemical method [11].

\section{Statistics}

Results for Study 1 were standardized to $100 \%$ on the mean of the immediately extracted, non-incubated duplicates. In Study 2 results for the +20 -and +150 -min samples were standardized to the immediate extract obtained after centrifugation at room temperature. Results are expressed as mean \pm SD unless otherwise indicated, and were analysed using Student's paired t-test, standard parametric analysis of variance and least squares correlation.

\section{Results}

Serum C-peptide concentrations were below 0.04 $\mathrm{nmol} / \mathrm{l}$ in all patients studied. IgG insulin binding was $6.8 \pm 4.8 \mu \mathrm{g} / \mathrm{l}$.

\section{Study 1: Influence of storage of plasma at -20 and $-40^{\circ} \mathrm{C}$, and the $\mathrm{pH}$ of incubation}

1. Normal control plasma. Measured insulin concentrations in the unextracted samples ranged from 3.9 to $47 \mathrm{mU} / 1$. After immediate PEG extraction and free insulin assay the largest deviation from the regular assay was $0.9 \mathrm{mU} / 1$ (at $38.7 \mathrm{mU} / 1$ ) and the largest percentage deviation a fall of $14 \%$ (from 3.9 to $3.4 \mathrm{mU} / 1$ ). Correlation between the two methods was strong $(r=0.999)$. Incubation of the immediate extracts before or after freezing did not affect the measured concentrations (Table 1). Incubation of plasma for $2 \mathrm{~h}$ at $37^{\circ} \mathrm{C}$ had no effect whether performed before or after deep freezing (Table 1). Similarly, incubation with or without $5 \% \mathrm{CO}_{2}$ followed by PEG extraction before storage, or incubation after storage followed by extraction, failed to disturb either the mean result or its scatter (Table 1).

2. Plasma from insulin-treated diabetic patients. Following precipitation of insulin antibodies immediately after centrifugation, incubation of PEG extracts at $37^{\circ} \mathrm{C}$ for $2 \mathrm{~h}$ and storage at $-20^{\circ} \mathrm{C}$, in either order, failed to disturb the measured free insulin result (Table 2).

Extracts of plasma prepared on the day of assay from plasma thawed and incubated at $37^{\circ} \mathrm{C}$ gave erratic results compared with the reference measurements
Table 1. Effect of different treatments of normal control plasma on the measured insulin concentration

\begin{tabular}{lclll}
\hline Treatment & $\begin{array}{l}\text { Concen- } \\
\text { tration }\end{array}$ & Range & $\begin{array}{l}\text { Corre- } \\
\text { lation }\end{array}$ & $\begin{array}{l}\text { Deviation } \\
\text { between } \\
\text { duplicates } \\
(\%)\end{array}$ \\
& $(\%)$ & $(\%)$ & $r$ & \\
\hline $\begin{array}{l}\text { Regular assay } \\
\text { Plasma }\end{array}$ & & & & \\
$\quad$ Immediate storage & $100 \pm 0$ & - & - & 4 \\
$\quad$ Incubated before storage & $96 \pm 5$ & $89-105$ & 0.998 & 5 \\
$\quad$ Incubated before assay & $101 \pm 4$ & $97-106$ & 0.999 & 4 \\
Free insulin assay & & & & \\
Immediate PEG extract & & & & \\
$\quad$ Immediate storage & $97 \pm 5$ & $86-103$ & 0.999 & 7 \\
$\quad$ Incubated before assay & $95 \pm 5$ & $92-105$ & 0.997 & 6 \\
Plasma & & & & \\
$\quad$ Incubated before storage & & & & \\
$\quad$ With $\mathrm{CO}_{2}$ & $96 \pm 7$ & $92-115$ & 0.999 & 8 \\
$\quad$ Without CO & $98 \pm 3$ & $95-113$ & 0.999 & 9 \\
$\quad$ Incubated before assay & $95 \pm 7$ & $87-105$ & 0.994 & 6
\end{tabular}

Mean $\pm \mathrm{SD}, n=10$. Results are expressed as a percentage of the mean result of the immediately separated duplicate aliquots assayed in the regular insulin assay. Correlations were sought with these mean results

Table 2. Effect of different treatments of plasma and PEG extracts on the measured free and total insulin concentrations in insulin-treated subjects

\begin{tabular}{|c|c|c|c|c|}
\hline Treatment & $\begin{array}{l}\text { Concen- } \\
\text { tration } \\
(\%)\end{array}$ & Range & $\begin{array}{l}\text { Corre- } \\
\text { lation } \\
r\end{array}$ & $\begin{array}{l}\text { Deviation } \\
\text { between } \\
\text { duplicates } \\
(\%)\end{array}$ \\
\hline \multicolumn{5}{|l|}{ Free insulin assay } \\
\hline \multicolumn{5}{|l|}{ Immediate PEG extract } \\
\hline Immediate storage & $100 \pm 0$ & - & - & 6 \\
\hline Incubated pre assay & $103 \pm 8$ & $89-113$ & 0.971 & 4 \\
\hline Incubated pre storage & $107 \pm 7$ & $96-114$ & 0.981 & 7 \\
\hline \multicolumn{5}{|l|}{ Plasma } \\
\hline \multicolumn{5}{|l|}{ Incubated after storage } \\
\hline$-20^{\circ} \mathrm{C}$ & $133 \pm 64$ & $51-272$ & 0.635 & 10 \\
\hline$-40^{\circ} \mathrm{C}$ & $93 \pm 37$ & $36-157$ & 0.716 & 6 \\
\hline Incubated with HEPES & $100 \pm 53$ & $41-188$ & 0.588 & 6 \\
\hline \multicolumn{5}{|l|}{ Incubated pre storage } \\
\hline With $\mathrm{CO}_{2}$ & $141 \pm 48$ & $87-246$ & 0.699 & 7 \\
\hline Without $\mathrm{CO}_{2}$ & $139 \pm 36$ & $86-187$ & 0.810 & 7 \\
\hline \multirow{2}{*}{\multicolumn{5}{|c|}{$\begin{array}{l}\text { Total insulin assay } \\
\text { Immediate Acid/PEG } \\
\text { extract }\end{array}$}} \\
\hline & & & & \\
\hline Immediate storage & $100 \pm 0$ & - & - & 10 \\
\hline Incubated pre assay & $98 \pm 5$ & $90-107$ & 0.999 & 11 \\
\hline Incubated pre storage & $97 \pm 7$ & $86-106$ & 0.997 & 7 \\
\hline \multicolumn{5}{|l|}{ Plasma } \\
\hline \multicolumn{5}{|l|}{ Incubated after storage } \\
\hline$-20^{\circ} \mathrm{C}$ & $90 \pm 12$ & 80115 & 0.985 & 8 \\
\hline$-40^{\circ} \mathrm{C}$ & $95 \pm 15$ & $73-115$ & 0.975 & 14 \\
\hline \multicolumn{5}{|l|}{ Incubated pre storage } \\
\hline With $\mathrm{CO}_{2}$ & $98 \pm 10$ & $85-118$ & 0.996 & 13 \\
\hline Without $\mathrm{CO}_{2}$ & $95 \pm 11$ & $84-118$ & 0.994 & 15 \\
\hline
\end{tabular}

Mean $\pm \mathrm{SD}, n=9$. Results are expressed as a percentage of the mean result of the immediately extracted duplicate aliquots. Correlations were sought with these mean results

(Table 2). Thus by $2 \mathrm{~h}$ mean concentration had increased by $33 \%$, this disguising a very wide scatter from a $49 \%$ lower value $(17.0$ to $8.6 \mathrm{mU} / 1)$ to an $172 \%$ increase $(23.3$ to $63.5 \mathrm{mU} / \mathrm{l})$. Five of the samples showed 
Table 3. Effect of temperature of centrifugation and incubation of plasma, and a brief incubation of plasma with rising and falling free insulin levels, on measured free insulin concentrations

\begin{tabular}{|c|c|c|c|}
\hline Treatment & $\begin{array}{l}\text { Concen- } \\
\text { tration } \\
(\%)\end{array}$ & $\begin{array}{l}\text { Range } \\
(\%)\end{array}$ & $\begin{array}{l}\text { Corre- } \\
\text { lation } \\
r\end{array}$ \\
\hline \multicolumn{4}{|l|}{ Rising insulin levels } \\
\hline \multicolumn{4}{|c|}{ Immediate PEG extract } \\
\hline \multicolumn{4}{|c|}{ Centrifuged at } \\
\hline $\begin{array}{l}4^{\circ} \mathrm{C} \\
\text { Room temp. }\end{array}$ & $\begin{array}{r}98 \pm 10 \\
100 \pm 0\end{array}$ & $\begin{array}{l}82-111 \\
-\end{array}$ & $\begin{array}{l}0.994 \\
-\end{array}$ \\
\hline $37^{\circ} \mathrm{C}$ & $97 \pm 11$ & $84-110$ & 0.994 \\
\hline \multicolumn{4}{|l|}{ Plasma } \\
\hline \multicolumn{4}{|c|}{ Incubated pre storage } \\
\hline $0^{\circ} \mathrm{C}$ & $69 \pm 14$ & $53-92$ & 0.978 \\
\hline Room temp. & $85 \pm 26$ & $43-114$ & 0.991 \\
\hline $37^{\circ} \mathrm{C}$ & $117 \pm 12$ & $102-130$ & 0.995 \\
\hline \multicolumn{4}{|c|}{ Incubation pre assay } \\
\hline $0^{\circ} \mathrm{C}$ & $140 \pm 40$ & $105-214$ & 0.992 \\
\hline $37^{\circ} \mathrm{C}$ & $150 \pm 77$ & $74-257$ & 0.853 \\
\hline \multicolumn{4}{|l|}{ Falling insulin levels } \\
\hline \multicolumn{4}{|c|}{ Immediate PEG extract } \\
\hline \multicolumn{4}{|l|}{ Centrifuged at } \\
\hline $4^{\circ} \mathrm{C}$ & $96 \pm 13$ & $85-121$ & 0.991 \\
\hline Room temp. & $100 \pm 0$ & - & - \\
\hline $37^{\circ} \mathrm{C}$ & $105 \pm 12$ & $87-124$ & 0.996 \\
\hline \multicolumn{4}{|l|}{ Plasma } \\
\hline \multicolumn{4}{|c|}{ Incubated pre storage } \\
\hline $0^{\circ} \mathrm{C}$ & $76 \pm 11$ & $65-92$ & 0.990 \\
\hline Room temp. & $93 \pm 8$ & $85-104$ & 0.997 \\
\hline $37^{\circ} \mathrm{C}$ & $123 \pm 21$ & $103-162$ & 0.991 \\
\hline
\end{tabular}

Mean $\pm \mathrm{SD}, n=6$. Results are expressed as a percentage of the mean result of the immediately extracted duplicate aliquots. Correlations were sought with these mean results

Table 4. Free insulin concentrations (mean \pm SEM) in plasma extracted with PEG immediately after venepuncture and centrifugation

\begin{tabular}{ll}
\hline $\begin{array}{l}\text { Time from injection } \\
\text { (min) }\end{array}$ & $\begin{array}{l}\text { Free insulin } \\
(\mathrm{mU} / 1)\end{array}$ \\
\hline 10 & $41 \pm 12$ \\
20 & $71 \pm 25$ \\
30 & $78 \pm 18$ \\
120 & $80 \pm 21$ \\
150 & $56 \pm 19$ \\
180 & $28 \pm 6$ \\
\hline
\end{tabular}

deviations of more than $30 \%$, and only two were within $10 \%$. Correlation with the reference samples fell to $r=0.635$. In contrast, the mean deviation between duplicates was $10.1 \%$, with a correlation of $r=0.998$.

This pattern of deviation from the reference samples was already established after only $0.5 \mathrm{~h}$ incubation of plasma at $37^{\circ} \mathrm{C}(124 \pm 50 \%$, range 40 to $210 \%)$, with no consistent change occurring in the following $1.5 \mathrm{~h}$.

The $\mathrm{pH}$ of this plasma after $1.75 \mathrm{~h}$ incubation was $8.24 \pm 0.12$ units. Addition of HEPES at the beginning of the incubation kept the final $\mathrm{pH}$ to $7.64 \pm 0.03$. Although the mean measured free insulin concentration was then normal $(100 \%)$, the scatter remained large (SD $53 \%$, range 41 to $188 \%$, correlation with reference concentrations $r=0.588$ ) again, with good agreement between duplicate aliquots (mean deviation 6.2\%) (Table 2).
Incubation of plasma on the day of venepuncture at $37^{\circ} \mathrm{C}$ also led to a rise in $\mathrm{pH}$ (to $7.86 \pm 0.15$ at $0.17 \mathrm{~h}$ and $8.14 \pm 0.09$ at $1.75 \mathrm{~h}$ ). Extraction with PEG after a $2.0 \mathrm{~h}$ incubation before freezing led to marked deviation in both mean measured free insulin concentration and scatter (Table 2). Incubation in a $\mathrm{CO}_{2}$ incubator maintained $\mathrm{pH}$ closer to the physiological level $(7.63 \pm 0.03$ at $1.75 \mathrm{~h}$ ), but mean deviation was identical and scatter rather greater (Table 2).

Plasma stored at $-40^{\circ} \mathrm{C}$ and then incubated for $2.0 \mathrm{~h}$ also showed erratic changes compared to reference concentrations (Table 2). Correlations between plasma stored at -20 and $-40^{\circ} \mathrm{C}(r=0.952)$ and plasma incubated with and without HEPES $(r=0.880)$ were relatively strong, despite poor correlations with reference measurements $(r=0.558$ to 0.716 , Table 2$)$, suggesting a common factor disturbing the measurements.

In contrast, total insulin measurements remained within a comparatively narrow range whether plasma was incubated with or without HEPES at $37^{\circ} \mathrm{C}$ (Table 2). Mean deviation between duplicates (reference samples $9.8 \%$ ) was rather higher with this more complex extraction procedure.

\section{Study 2: Effect of temperature of centrifugation, and temperature of incubation of plasma during rising and falling insulin concentrations}

At both +20 and +150 min the measured free insulin concentrations were independent of the temperature of the brief centrifugation (Table 3 ).

Plasma insulin concentrations were rising at +20 min and falling at $+150 \mathrm{~min}$ in all cases (Table 4 ). Delaying the extraction of the $+20 \mathrm{~min}$ sample by a 30 -min incubation at 0 or $37^{\circ} \mathrm{C}$ gave lower $(68 \pm 6 \%$ (mean $\pm \mathrm{SE}), p<0.02)$ or higher $(117 \pm 5 \%, p<0.05)$ values respectively. Similar percentage changes were seen at $+150 \min (76 \pm 5$ and $123 \pm 9 \%$, both $p<0.05)$, and were not significantly different from the changes at +20 min by analysis of variance $(F=1.81$, NS), suggesting the changes were independent of whether insulin concentrations were rising or falling at the time of venepuncture.

As with Study 1, incubation of plasma on the day of assay for $2 \mathrm{~h}$ at $37^{\circ} \mathrm{C}$ before PEG extraction caused considerable scattering of results (range 74 to $257 \%$ ). Incubation of plasma at $0{ }^{\circ} \mathrm{C}$ also disturbed both the mean results (to 140\%) and the scatter (SD 39\%, range 105 to $214 \%$ ). The good correlation with reference concentrations at this temperature is because the absolute change $(16 \pm 9 \mathrm{mU} / 1)$ was consistent throughout the range of free insulin concentrations studied.

\section{Discussion}

The requirement for methods for the analysis of free insulin arises from the presence of insulin antibodies within the circulation of insulin-treated diabetic patients [1]. Ideally the estimated free insulin level in plas- 
ma should represent the biologically active unbound insulin in the blood at the time of venepuncture. Such a measurement dictates that there should be no perturbation of insulin/antibody status up to the time of extraction of gammaglobulin. Maintenance of this status quo is likely to be particularly difficult if the system is not in equilibrium. It is reassuring, therefore, that incubation of plasma at $0^{\circ} \mathrm{C}$, room temperature, or $37^{\circ} \mathrm{C}$ after immediate separation but prior to extraction with PEG produced identical decreases and increases in the measured free insulin values independent of whether insulin concentrations were rising or falling (Table 3 ). It could be argued that equilibrium might have been established in the first minute after venepuncture. However, since the measured free insulin value was independent of the temperature of centrifugation of the blood, it is unlikely that significant changes could have occurred during the 60 -s centrifugation.

The measured free insulin results of those plasma samples incubated immediately after separation show a typical temperature dependence with lower temperatures favouring association of the insulin antibody complex, hence producing lower free insulin levels. Unexpectedly, free insulin concentrations tended to drift up even when plasma was incubated at body temperature, a phenomenon that continued with the longer incubation period and was not related to $\mathrm{pH}$ changes as a result of loss of $\mathrm{CO}_{2}$ with time (Table 2).

The studies with plasma from normal subjects confirm that PEG treatment does not disturb measured insulin values in the absence of insulin antibodies (Table 1). Furthermore, the other manipulations used in the present study (incubation before or after storage, with or without adjustment of $\mathrm{pH}$ ) do not influence insulin measurements in non-insulin treated subjects. Thus the presence of PEG in the extract obtained after an immediate centrifugation, and therefore throughout incubations, freezing, thawing and assay, gave very comparable results ( $r$ always $>0.994$ ) to direct assay. This is important to the validity of our choice of immediately extracted plasma as reference samples in the insulin-treated patient studies. The stability of the reference values was confirmed by the incubation of the extracts for $2 \mathrm{~h}$ at $37^{\circ} \mathrm{C}$ before or after freezing, without marked perturbation of the measured free insulin concentration (Table 2).

In contrast, nearly any manipulation of diabetic plasma disturbed the free insulin results, though duplicate aliquots behaved very similarly (Table 2 ). In particular, stored plasma samples incubated (as generally recommended [5]) before extraction on the day of assay gave very unpredictable results in both Study 1 and Study 2. This was independent of $\mathrm{pH}$, temperature of storage, or the temperature of incubation. As total insulin concentrations were comparatively stable, and as some samples showed a drop and some a rise in apparent free insulin concentration, it seems unlikely that this simply reflects degradation of insulin antibody complexes.

Kuzuya et al. [5] showed that samples incubated at $37^{\circ} \mathrm{C}$ for increasing times prior to extraction gave variable results. Some samples gave steadily increasing results over $16 \mathrm{~h}$, while others increased and then fell again. An incubation time of $2 \mathrm{~h}$ was suggested as giving values which probably resembled in vivo levels most closely. From the results of the present study, however, it seems mandatory that samples be extracted immediately at the time of venepuncture for the accurate estimation of free insulin in diabetic patients. This will overcome subsequent problems of changes in free insulin which can lead to erratic results. The use of plasma rather than serum allows rapid removal of insulin antibodies, minimising changes in bound insulin.

Acknowledgements. We are grateful for the support of Novo Laboratories Limited and the British Diabetic Association. Dr. P.D. Home is a Wellcome Trust Senior Research Fellow in Clinical Science.

\section{References}

1. Berson SA, Yalow RS (1964) The present state of insulin antagonists in plasma. Diabetes 13: 247-259

2. Nakagawa S, Nakayama H, Sasaki T, Yoshino K, Yu YY, Shinozaki K, Aoki S, Mashimo K (1973) A simple method for the determination of serum free insulin levels in insulin-treated patients. Diabetes 22: $590-600$

3. Heding LG (1969) Determination of free and antibody-bound insulin in insulin treated diabetic patients. Horm Metab Res 1: 145-146

4. Asplin CM, Goldie DJ, Hartog M (1977) The measurement of serum free insulin by steady-state gel filtration. Clin Chim Acta 75: 393-399

5. Kuzuya H, Blix PM, Horwitz DL, Steiner DF, Rubenstein AH (1977) Determination of free and total insulin and C-peptide in insulin-treated diabetics. Diabetes 26: 22-29

6. Desbuquois B, Auerbach GD (1971) Use of polyethylene glycol to separate free and antibody bound peptide hormones in radioimmunoassay. J Clin Endocrinol 33: 732-738

7. Goldman J, Baldwin D, Pugh W, Rubenstein AH (1978) Equilibrium binding assay and kinetic characterisation of insulin antibodies. Diabetes 27:653-660

8. Hales CN, Randle PJ (1963) Immunoassay of insulin with an insulin-antibody precipitate. Biochem J 88: 137-146

9. Soeldner J, Slone D (1965) Critical variables in the radioimmunoassay of serum insulin using the double antibody technic. Diabetes 14: 771-779

10. Heding LG (1975) Radioimmunological determination of human C-peptide in serum. Diabetologia 11:541-548

11. Reeves WG, Kelly U (1980) An immunochemical method for the quantitation of insulin antibodies. J Immunol Methods 34: $329-338$

Received: 10 April 1985

and in revised form: 9 September 1985

Dr. P. D. Home

Department of Medicine

Royal Victoria Infirmary

Newcastle upon Tyne

NE1 4LP

UK 